\title{
EFFECT OF TEMPERATURE UNDER FIELD CONDITIONS ON THE REPRODUCTIVE PERFORMANCE OF EWES
}

\author{
W. E. NEVILLE, JR* AND M. W. NEATHERY† \\ University of Georgia, Georgia Station, Experiment, Georgia 30212, and \\ Georgia Mountain Experiment Station, Blairsville, Georgia 30512, U.S.A.
}

(Received 20th August 1973)

It has been established that reproductive performance of ewes during the breeding period is adversely affected by constant high ambient temperatures of 32 to $35^{\circ} \mathrm{C}$ (Alliston \& Ulberg, 1957, 1961; Dutt, Ellington \& Carlton, 1959; Dutt, 1963) and favourably affected by constant low ambient temperatures of 16 to $21^{\circ} \mathrm{C}$ (Alliston \& Ulberg, 1957; Wilson, Godley \& Hurst, 1961; Godley, Wilson \& Hurst, 1966). In commercial practice, however, ewes are subjected to prevailing diurnal atmospheric conditions. Any occurrence of heat stress in ewes during the breeding period is likely to be limited to a portion of a particular 24-hr period. Thus, heat stress under natural diurnal temperature variation may have less adverse effects on the ova, their fertilization, development and subsequent lambing percentage as compared with the effects of constant, prolonged heat stress. Few detailed reports of this nature are available, however, and have been limited to conditions simulating normal diurnal variability (Yeates, 1956; Ryle, 1961; Smith, Bell \& De Chaneet, 1966; Thwaites, 1967, 1969). The purpose of this investigation was to evaluate natural differences in atmospheric temperature during the summer breeding period at two geographic locations for their effect on the reproductive performance of ewes.

The data were collected over a 2-year period at two locations, Experiment and Blairsville, Georgia. Experiment is $299 \mathrm{~m}$ in elevation and Blairsville, $246 \mathrm{~km}$ north of Experiment, is $584 \mathrm{~m}$ in elevation in the Georgia Mountain area. The ewes at Experiment were crossbreds, approximately 50\% Hampshire and $50 \%$ Rambouillet. During the first year, the ewes at Blairsville were all high grade Hampshires. During the second year, approximately $50 \%$ were high grade Hampshire and the remainder were first-cross Dorset $\times$ Hampshire. Because the ewes at each location differed in genotype, a representative number of the ewes at Experiment was moved each year to Blairsville and a representative portion of the Blairsville ewes was moved to Experiment in May and returned to their original locations in mid-September. All ewes were sheared just before transfer in May. Immediately after transfer of the ewes, raddled vasectomized rams were turned in with all ewes to detect the first

\footnotetext{
* Present address: Department of Animal Science, Georgia Coastal Plain Experiment Station, Tifton, Georgia 31794, U.S.A.

+ Present address: Department of Dairy Science, University of Georgia, Athens, Georgia 30602, U.S.A.
} 
oestrus following anoestrus. Two days after first oestrus, each ewe was assigned to a particular pasture for breeding with consideration for the date of first oestrus, the age of the ewe and the breed of the ewe where applicable. Each year, some of the ewes at each location served as a controls while other ewes received a subcutaneous injection of 1000 i.u. PMSG on either the 13th or 14th day (oestrus = Day 0 ) of the oestrous cycle. The PMSG was given to increase multiple ovulations followed by multiple fetuses, thus providing conditions which were assumed to be more sensitive than those in ewes not receiving PMSG for detecting the effect of temperature on early embryonic mortality.

One intact raddled ram which had been tested for fertility was placed with each set of ewes and stayed with them continuously for 17 days. The ewes

Table 1. Mean maximum and minimum temperatures shown by years, location and months

\begin{tabular}{|c|c|c|c|c|c|}
\hline \multirow[b]{2}{*}{ rear } & \multirow[b]{2}{*}{ Date } & \multicolumn{2}{|c|}{ Experiment } & \multicolumn{2}{|c|}{ Blairsville } \\
\hline & & $\begin{array}{l}\text { Mean } \\
\text { max. }\end{array}$ & $\begin{array}{c}\text { Mean } \\
\text { min. }\end{array}$ & $\begin{array}{l}\text { Mean } \\
\text { max. }\end{array}$ & $\begin{array}{c}\text { Mean } \\
\text { min. }\end{array}$ \\
\hline First & $\begin{array}{l}\text { May } 16 \text { to } 31 \\
\text { June } 1 \text { to } 30 \\
\text { July } 1 \text { to } 31 \\
\text { Aug. } 1 \text { to } 31 \\
\text { Sept. } 1 \text { to } 14\end{array}$ & $\begin{array}{l}31 \cdot 1 \\
31 \cdot 5 \\
32 \cdot 8 \\
31 \cdot 1 \\
31 \cdot 1\end{array}$ & $\begin{array}{l}16 \cdot 7 \\
18 \cdot 7 \\
21 \cdot 0 \\
20 \cdot 4 \\
18 \cdot 7\end{array}$ & $\begin{array}{l}26 \cdot 9 \\
27 \cdot 0 \\
26 \cdot 8 \\
28 \cdot 3 \\
28 \cdot 0\end{array}$ & $\begin{array}{r}8 \cdot 6 \\
13 \cdot 3 \\
15 \cdot 6 \\
16 \cdot 2 \\
14 \cdot 2\end{array}$ \\
\hline Second & $\begin{array}{l}\text { May } 16 \text { to } 31 \\
\text { June } 1 \text { to } 30 \\
\text { July } 1 \text { to } 31 \\
\text { Aug. } 1 \text { to } 31 \\
\text { Sept. } 1 \text { to } 14\end{array}$ & $\begin{array}{l}26 \cdot 0 \\
28 \cdot 6 \\
31 \cdot 0 \\
30 \cdot 1 \\
30 \cdot 4\end{array}$ & $\begin{array}{l}13 \cdot 1 \\
17 \cdot 5 \\
19 \cdot 6 \\
19 \cdot 4 \\
20 \cdot 5\end{array}$ & $\begin{array}{l}20 \cdot 4 \\
23 \cdot 9 \\
26 \cdot 1 \\
26 \cdot 9 \\
27 \cdot 6\end{array}$ & $\begin{array}{r}6 \cdot 1 \\
12 \cdot 2 \\
13 \cdot 6 \\
13 \cdot 9 \\
14 \cdot 4\end{array}$ \\
\hline
\end{tabular}

Temperatures are expressed in ${ }^{\circ} \mathrm{C}$.

were then rotated between sets as a means of reducing possible ram effects. Intact rams remained with ewes until mid-September each year. All ewes stayed continuously on bermuda grass (Cynodon dactylon) pasture during the summer and autumn. Subsequently, they were fed good quality hay and a grain mixture which permitted them to stay in a weight-gaining condition up to lambing. The data were analysed by analyses of variance using the method of fitting constants.

The mean maximum temperature averaged $5^{\circ} \mathrm{C}$ cooler at Blairsville than at Experiment during June and July when most of the ewes were bred (Table 1). During these 2 months, there were 28 days in the first year and 11 days in the second year when the temperature exceeded $32 \cdot 2^{\circ} \mathrm{C}$ at Experiment, but at no time during either summer was this temperature exceeded at Blairsville.

Of the 277 ewes mated (marked by intact rams), thirty-three failed to lamb. The number of oestrous periods which each of these ewes had while exposed to intact rams was analysed by analysis of variance. Neither of the four main effects (year, source of ewe, summer location, hormone treatment) nor their first-order interactions significantly affected the number of their oestrous periods which had a least squares mean of 1.51. Possibly, some of these ewes which did not conceive on first or second oestrus, with intact rams, i.e. the ewes' second or 
third oestrus since their first was with vasectomized rams, subsequently entered a period of anoestrus. Research in Alabama (Shelton, 1966) indicated that oestrous activity during the summer months reaches a peak during June and subsides to anoestrus during July and August in certain ewes. There is also a possibility (Thwaites, 1969) that embryonic deaths occurred at a developmental stage late enough to prevent some of the thirty-three ewes from returning to oestrus for breeding before mid-September.

Table 2. Least squares means and constants for factors associated with ewe productivity

\begin{tabular}{|c|c|c|c|c|c|}
\hline & \multirow[b]{2}{*}{ Item } & \multirow[b]{2}{*}{$\begin{array}{l}\% \text { Ewes not } \\
\text { lambing }\end{array}$} & \multicolumn{3}{|c|}{$\%$ Lamb crop in terms of: } \\
\hline & & & Lambs born & $\begin{array}{c}\text { Lambs born } \\
\text { alive }\end{array}$ & $\begin{array}{c}\text { Lambs alive } 48 \mathrm{hr} \\
\text { after birth }\end{array}$ \\
\hline \multicolumn{2}{|c|}{$\begin{array}{l}\text { Results based on a total of } \\
277 \text { ewes mated by intact } \\
\text { rams, of which thirty-three } \\
\text { failed to lamb } \\
\text { Least squares mean }\end{array}$} & $15 \cdot 4$ & 123 & 108 & 98 \\
\hline Year & $\begin{array}{l}1 \\
2\end{array}$ & $\begin{array}{l}15 \cdot 0 \\
15 \cdot 8\end{array}$ & $\begin{array}{l}124 \\
122\end{array}$ & $\begin{array}{l}111 \\
104\end{array}$ & $\begin{array}{r}103 \\
93\end{array}$ \\
\hline $\begin{array}{l}\text { Source of } \\
\text { ewes }\end{array}$ & $\begin{array}{l}\text { Experiment } \\
\text { Blairsville }\end{array}$ & $\begin{array}{r}7 \cdot 5^{* *} \\
23 \cdot 3^{* *}\end{array}$ & $\begin{array}{l}132 \\
115\end{array}$ & $\begin{array}{l}117 \\
97\end{array}$ & $\begin{array}{r}110^{*} \\
85^{*}\end{array}$ \\
\hline $\begin{array}{l}\text { Summer } \\
\text { location }\end{array}$ & $\begin{array}{l}\text { Experiment } \\
\text { Blairsville }\end{array}$ & $\begin{array}{l}18 \cdot 5 \\
12 \cdot 4\end{array}$ & $\begin{array}{l}119 \\
127\end{array}$ & $\begin{array}{l}106 \\
109\end{array}$ & $\begin{array}{r}96 \\
100\end{array}$ \\
\hline $\begin{array}{l}\text { Hormone } \\
\text { treatment }\end{array}$ & $\begin{array}{l}\text { Control } \\
\text { PMSG }\end{array}$ & $\begin{array}{l}12 \cdot 4 \\
18 \cdot 5\end{array}$ & $\begin{array}{l}101^{* *} \\
145^{* *}\end{array}$ & $\begin{array}{r}95^{*} \\
121^{*}\end{array}$ & $\begin{array}{r}85^{*} \\
111^{*}\end{array}$ \\
\hline \multicolumn{2}{|c|}{$\begin{array}{l}\text { Results based on the } 244 \\
\text { mated ewes which sub- } \\
\text { sequently lambed } \\
\text { Least squares mean }\end{array}$} & - & 146 & 127 & 115 \\
\hline Year & $\begin{array}{l}1 \\
2\end{array}$ & - & $\begin{array}{l}146 \\
146\end{array}$ & $\begin{array}{l}129 \\
125\end{array}$ & $\begin{array}{l}119 \\
111\end{array}$ \\
\hline $\begin{array}{l}\text { Source of } \\
\text { ewes }\end{array}$ & $\begin{array}{l}\text { Experiment } \\
\text { Blairsville }\end{array}$ & - & $\begin{array}{l}141 \\
151\end{array}$ & $\begin{array}{l}127 \\
127\end{array}$ & $\begin{array}{l}119 \\
112\end{array}$ \\
\hline $\begin{array}{l}\text { Summer } \\
\text { location }\end{array}$ & $\begin{array}{l}\text { Experiment } \\
\text { Blairsville }\end{array}$ & - & $\begin{array}{l}147 \\
146\end{array}$ & $\begin{array}{l}129 \\
125\end{array}$ & $\begin{array}{l}117 \\
113\end{array}$ \\
\hline $\begin{array}{l}\text { Hormone } \\
\text { treatment }\end{array}$ & $\begin{array}{l}\text { Control } \\
\text { PMSG }\end{array}$ & $\overline{-}$ & $\begin{array}{l}115^{* *} \\
178^{* *}\end{array}$ & $\begin{array}{l}108^{* *} \\
147^{* *}\end{array}$ & $\begin{array}{r}97^{* *} \\
134^{* *}\end{array}$ \\
\hline
\end{tabular}

* $P<0.05$ between two vertical means within a sub-set.

** $P<0.01$ between two vertical means within a sub-set.

The conception rate of the 244 ewes which lambed was not significantly affected by either of the four main effects or their first-order interactions. Least squares mean conception rate was $1 \cdot 12$ for these ewes.

Table 2 shows the results of analyses of variance for factors associated with ewe productivity on the basis of ewes mated (marked by intact rams) and ewes that lambed. The least squares mean indicated that $15.4 \%$ of the ewes which were mated did not lamb. The percentage of ewes not lambing $(P<0.01)$ and the number of lambs alive $48 \mathrm{hr}$ after birth $(P<0.05)$ were significantly affected by source of ewes only in the 'ewes mated' analyses. The PMSG treatment significantly increased the percentage of lambs born and living both in terms of 
ewes mated and ewes lambing, showing that the ewes given PMSG had a higher ovulation rate and more embryos per ewe than the control ewes.

Of the forty-two first-order interactions among the main effects for ewes bred and for ewes lambing, only ewe source $\times$ hormone treatment for the percentage of ewes not lambing was significant $(P<0.05)$. It showed that among ewes at Experiment a higher percentage of the control ewes failed to. lamb as compared with those treated with PMSG while the opposite was true for Blairsville ewes.

Although the location at Blairsville was cooler than at Experiment during the breeding period, summer location was not a significant source of variation in any of the measures of ewe productivity examined. Furthermore, the lack of statistical significance for the first-order interaction of hormone treatment $x$ summer location indicated that any difference in heat stress due to location was not detected in the ewes treated with PMSG which, presumably, were more sensitive to heat stress than the control ewes. A greater difference in environmental temperature than that which occurred between the locations at Blairsville and Experiment, and a greater heat stress than that which was imposed at Experiment, are probably needed before a statistically significant difference in various measures of ewe productivity can be detected. Thus, these results provide information which should be useful in identifying areas of natural diurnal temperature which are not likely to affect reproductive performance in ewes.

\section{REFERENCES}

Alliston, G. W. \& Ulberg, L. G. (1957) Early embryonic development of sheep. Proc. Ass. sth. agric. Wkrs, 54, 89, Abstr.

Alliston, C. W. \& UlberG, L. C. (1961) Early pregnancy loss in sheep at ambient temperatures of $70^{\circ}$ and $90^{\circ} \mathrm{F}$. as determined by embryo transfer. F. Anim. Sci. 20, 608.

Dutr, R. H. (1963) Critical period for early embryo mortality in ewes exposed to high ambient temperature. F. Anim. Sci. 22, 713.

Dutt, R. H., Ellington, E. F. \& Garlton, W. W. (1959) Fertilization rate and early embryo survival in sheared and unsheared ewes following exposure to elevated air temperature. F. Anim. Sci. 18, 1308.

Godley, W. C., Wilson, R. L. \& Hurst, V. (1966) Effect of controlled environment on reproductive performance of ewes. F. Anim. Sci. 25, 212.

RYLE, M. (1961) Early reproductive failure of ewes in a hot environment. I. Ovulation rate and embryonic mortality. 7. agric. Sci., Camb. $57,1$.

Shelton, M. (1966) Seasonal breeding. In: Sheep research in the southern region, pp. 15-16. Southern Coop. Series Bull. No. 119.

Smith, I. D., Bell, G. H. \& De Chaneet, G. (1966) Embryonic mortality in Merino ewes exposed to high ambient temperatures. Aust. vet. F. 42, 468.

Thwaites, G. J. (1967) Embryo mortality in the heat stressed ewe. I. The influence of breed. F. Reprod. Fert. 14, 5 .

Thwartes, G. J. (1969) Embryo mortality in the heat stressed ewe. II. Application of hot-room results to field conditions. $\mathcal{F}$. Reprod. Fert. 19, 255.

Wilson, R. L., Godley, W. G. \& HURst, V. (1961) Effect of light, temperature and hormones on the reproductive performance of ewes. F. Anim. Sci. 20, 693.

YeAtes, N. T. M. (1956) The effect of high air temperature on pregnancy and birth weight in Merino sheep. Aust. J. agric. Res. 7, 435. 